\title{
Client-Centricity In South African Retail Banking
}

Johan Coetzee, University of the Free State, South Africa

\begin{abstract}
Client-centricity deals with addressing the needs of clients as they change. It requires contactpersonnel who are empowered to not only identify client needs, but address them speedily. This study investigated the perceptions of client-centricity for 559 contact-personnel at three major South African retail banks in central South Africa. The results indicate that in general the contact personnel regard their respective banks as enforcing a client-centric strategy. They do however feel that the support from administrative personnel and the processes that support the sales environment are not always conducive to client-centric principles. This is a particular problem as contact-personnel are attuned to addressing the sales-related product and service offerings of clients as opposed to the process-related administrative burdens attached to the delivery of such products and services. The study also found that the job function of contact-personnel is the most important factor to consider when developing a client-centric strategy. Further to this, contactpersonnel with the longest number of years of experience in a specific function are the best to use for management when determining whether or not specific tools to achieve client-centricity are effective. The major contribution of the study is that it focuses specifically on the perceptions of contact-personnel and thus provides additional knowledge of what the bank (through its clientfacing staff) itself considers important with regards to client-centricity.
\end{abstract}

Keywords: Client-Centricity; Retail Banking; Contact-Personnel; South Africa

\section{BACKGROUND AND OBJECTIVES OF THE STUDY}

1 n order to ensure sustainable organisational growth, banks have diversified their revenue streams to reflect changing consumer behaviour. This has led to banks re-assessing their relationship with clients in order to align their product and service offerings towards satisfying the needs of clients. This clientcentric approach contrasts the previous approaches by banks to merely provide products and services and segmenting markets accordingly. Rather, it aims to identify different market segments and concomitantly customise product and service offerings according to specific client needs (Auerbach, Argimon, Hieronimus, Roland, \& Teschke, 2012; Lymberopoulos, Chaniotakis, \& Soureli, 2004). This strategy is exacerbated given the adverse effects that the global financial crisis has had on the trust clients have for banks (Bogaerts, 2011). Keeping clients at the core of strategic intentions is applicable to those both current and prospective as the major driver of this approach is to prevent clients from migrating to other banks by ensuring that they are satisfied and loyal to the respective bank. Client-centricity is therefore a proactive client acquisition and retention strategy aimed to consistently identify and address client needs. This client-centric approach has forced banks to become acutely aware of the way they interact with clients by being both more responsive and proactive to dynamically changing client needs. By their very nature the intermediation function of a bank enables it to be responsive to client needs as it is able to gather proprietary client information and in so doing, add value to clients (Scholtens \& Van Wensveen, 2000, p. 1250). Sinkey (2002, p. 91) compares banks to communication firms in that they "both establish networking relationships through which they collect, store, process, and transmit information for themselves and customers' accounts." Rose \& Hudgins (2010, p. 13) state that the success of banks "hinges on their ability to identify the financial services the public demands, produce those services efficiently, and sell them to the public at a competitive price." 
The problem, however, is that in recent decades the pressure placed on banks both locally and internationally to retain their clients has increased substantially. The 2012 Ernst \& Young Global Consumer Banking survey found that $34 \%$ of global respondents have changed their main bank and of these, $74 \%$ have done so in the last decade (Ernst \& Young, 2012, p. 8). In South Africa, the trend to switch banks has increased from 34\% in 2011 to 39\% in 2012 (Ernst \& Young, 2012, p. 8). A further study conducted by PwC (201, p. 54) found that South African clients are "more enabled to switch to a competitor bank at the slightest dissatisfaction or enticement." In fact, the study found that clients would not necessarily close bank accounts, but leave without notifying the bank ( $\mathrm{PwC}, 2013$, p. 13). The bank is therefore in many situations not aware of switching clients, but runs the risk of dormant accounts that are costly to keep on its books. Banks are therefore forced to monitor client activity more aggressively from not only a cost (or risk) management point of view, but also a needs-based and thus cross-selling point of view: "[b]anks have started to use big data as a strategic asset to identify customer needs and then to offer a wider range of services to match those needs" (PwC, 2013, p. 54).

These studies suggest very strongly that clients are becoming more demanding, less loyal, and engaging in multiple banking relationships that is eroding bank profitability. If banks require maximising the revenue generated per client and avoid losing them to competitors, they need to create an environment that is conducive to not only acquisition but also retention. The way banks interact with clients, especially in the branch environment that is associated with both service- and information-gathering encounters, is therefore vital to ensuring satisfaction and eventual retention. For example, the Ernst \& Young study of 2012 found that $76 \%$ of the South Africa respondents regarded face-to-face communication with trusted sources including family, friends, and colleagues as the most important source of information of bank products and services - this is higher than the global average of $71 \%$ (Ernst \& Young, 2012, p. 15). Added to this, financial advisors within banks were regarded by $72 \%$ of respondents as an important source of information on banks - this is substantially higher than the global average of $60 \%$ (Ernst \& Young, 2012, p. 15). Clients therefore consider physical face-to-face interactions with the bank as vitally important not only as a source of information about the bank's offerings, but also as a measure of being satisfied and secure with the bank: "[s]ome customers feel more secure if they are able to see their bank" (PwC, 2013, p. 51). This follows that the extent to which contact-personnel in branches are empowered to service the clients is crucial (Selden, 2007) as contact-personnel collect client information and effectively act as the intermediary between the client and the bank to facilitate the client-centric principles upon which the bank functions. The success of being client-centric, therefore, is comprised of addressing client needs on the one hand, and empowering contact-personnel to service clients on the other.

This study focuses on investigating the client-centric nature of retail banks by focusing specifically on the perceptions of client-facing contact-personnel in branches of three of the four major South African banks in central South Africa. More specifically, the objectives of this study are to:

- $\quad$ identify the most important aspects of client-centricity identified by contact-personnel in retail bank branches in central South Africa;

- $\quad$ identify the importance of the different aspects of client-centricity for contact-personnel with specific demographic features namely job title, location of branch, name of bank, years working at the bank, and years in the specific job position;

- identify how contact-personnel are empowered through the relevant tools that the bank provides them with, to offer client-centric services;

- $\quad$ identify the importance of specific tools of client-centricity by contact-personnel with specific demographic features, namely job title, location of branch, name of bank, years working at the bank, and years in the specific job position.

Although several studies have highlighted the relational aspects of bank-client relationships in South Africa (see the literature review below), the notion of client-centricity as such has not be explored. This study attempts to fill this gap in that it considers the view of only bank contact-personnel and was conducted in a region of South Africa that is not a major economic contributor to the South Africa economy. Central South Africa was investigated because the nature of the relationship that the contact-personnel have with clients is presupposed to be of a more intimate nature given the rural-based (as opposed to metropolitan-based in the larger economic hubs such as Johannesburg, Pretoria, Cape Town, and Durban) nature of banking in this region. Because clients in this region 
tend to be more dependent on face-to-face banking given the lower levels of economic activity, the smaller travelling distances, and the generally lower levels of financial literacy and education, contact-personnel in these smaller branches engage more intimately and on a more regular basis with clients than, one can argue, those who are in the hustle and bustle of the large metropolitan areas (see Coetzee, 2009). This rationale was used as the basis for selecting both the contact personnel and central South Africa as the sample and area of investigation for this study.

\section{LITERATURE REVIEW}

\subsection{The Characteristics of Client-Centric Organisations}

Several authors have identified a host of organisational characteristics that can be used to illustrate a clientcentric (or client-engaged) organisation. Band \& Guaspari (2003, pp. 36-39) state that they should deliver maximum value to clients through all its employees and that "customer-engagement" and the integration of "customer value insights" are integral to ensuring that an organisation has a client-centric focus. Simply put, a customer-engaged organisation is one that understands its customers and is willing to take action based on its knowledge of them (Band $\&$ Guaspari, 2003, p. 39). Auerbach et al. (2012) suggest that given the popularity of social media platforms and their potentially devastating effects on sales and reputation, banks can no longer afford to avoid customer needs. There must be a concerted effort to align banking products and services to customer needs.

Within this context of client-centricity, Singh (2004, p. 187) points out that banks should "listen" to clients in order to deliver products that "that they are willing to pay for." Hislop, Peterson, \& Ziegler (2002, p. 4) refer to having a "holistic understanding of the customer's needs," and adding value to client offerings is seen as a key differentiator in a client-centric organisation by Devlin (2000, p. 222). Kilgore, Kolatch, \& Colbeck (2005, pp. 4-8) indicate that the core themes surrounding a client-centric approach are to create value for the client by offering a "tailor-made" experience through convenience, to provide a sustainable relationship based on "value creation," and to improve relationships with the client through "superior service." Devlin (2000, p. 222) refers to value being created by offering a "competitive bundle of benefits." Furthermore, the research of Selden (2007) provides an insightful perspective on the dynamics surrounding client-centricity. He (2007, pp. 17-23) suggests four "building blocks" that an organisation can implement to become client-centric. These are to implement a report system that regularly provides information on customer profitability, to ensure that business units must be driven by needs-based customer segmentation, to ensure that each customer segment has a clearly defined value proposition, and to ensure that contact-personnel are educated and empowered to address client needs. The contact-personnel therefore play an integral part in the process of client-centricity.

The idea of client-centricity is therefore focused on addressing the holistic needs of clients rather than on the mere provision of products. Specifically, it refers to what products and services must be offered, how they are delivered, and to what extent the needs of clients are consistently being met by doing this. As suggested by Selden (2007, p. 22), it is a multi-faceted approach that is not limited to merely meeting client needs, but rather meeting them on a consistent basis as they change. Auerbach et al. $(2012$, p. 4) similarly provide the example of Apple as "[p]utting users at the centre of the product universe." Aligning the organisation, be that through product- and service-related processes or empowering contact-personnel, to identify and address the needs of clients is therefore crucially important when striving to be client-centric. Providing a platform for being innovative within the context of being client-centric is suggested by Selden and MacMillan (2006, p. 110) to provide several organisational benefits. These include creating a better understanding of clients' needs that are often "opaque" to competitors. Secondly, because contact-personnel are central to the process, it results in improved service delivery and lower employee turnover; third, a process of "deep learning" occurs that ultimately closes the growth gap between organisational plans and market expectations.

\subsection{The Response of Banks to Client-Centricity: The Convergence of Financial Services}

Given that client-centricity requires a bank to, as Dohmen, Moormann, \& Rosemann (2009, p. 385) state it, address the needs of clients from an "outside-in perspective," the challenge is to manage the information they gather as well as the information clients have at their disposal. Given that a central tenet of client-centricity is to address the needs of clients, Nayyar (1990, p. 513) indicates that diversified service firms such as banks can exploit information 
asymmetries and cross-sell additional products due to being able to provide a more complete product and service offering to clients. However, in an era where factors such as increased competition, globalisation, technological change, and geographical expansion have all resulted in banks becoming more sensitive to the needs of clients merely to survive, being privy to information has become a difficult task. These factors are so influential that some refer to the effect on the financial services industry as revolutionary (Rose \& Hudgins, 2010). As suggested by Florin-Mihai (2013), client-centricity is regarded as a key competitive differentiator that attracts market share.

The ubiquitous nature of information has, in turn, resulted in traditional norms of client expectations, behaviours, and value perceptions becoming not only distorted, but also more complex. Clients are becoming more hands-on, more distrustful, better-informed, more discerning, and more demanding in their relationships and interactions with banks (Hedley, White, Petit, \& Banerjea, 2005). As such, a key strategic driver for banks to gain competitive advantage is to optimise the potential of each bank-client relationship to ensure maximum responsiveness of client needs and behavioural patterns, thus becoming more client-centric. Therefore, being clientcentric goes hand-in-hand with mutually beneficial bank-client relationships.

Given this background, banks have responded to being more client-centric by expanding their business operations into non-traditional banking activities in order to be more aligned to market demands. More specifically, banks have expanded (or converged) their menu of products and services to include not only traditional banking products and services, but also insurance products and services. This convergence is commonly known as 'bancassurance' in France and South Africa, 'allfinanz' in Germany, and 'universal banking' in the United States and Great Britain (Rose \& Hudgins, 2010, p. 19; Staikouras, 2006, p. 125; Bergendahl, 1995, p. 17). Artikis, Mutenga, \& Staikouras (2008, p. 119) refer to bancassurance as a "form of corporate restructuring...[resulting from] calls for further integration" and Rose \& Hudgins (2010, p. 22) define it as the "movement of businesses across industry lines so that a firm formerly offering only one product line ventures into other product lines to broaden its sales base." This has resulted in the revenues from banks expanding to include non-interest activities as a major source of operating income.

Convergence therefore offers a holistic approach to addressing client needs by acting as a 'one-stop' financial services institution that effectively reduces the transaction costs for clients (Artikis et al., 2008, p. 114; Rose \& Hudgins, 2010, p. 13). This in turn enables banks to offer more comprehensive financial services offerings through "cross-selling and product bundling agreements...[that] is most evident at bank branches" (Okeahalam, 2008, p. 147). Therefore, the practice of bancassurance shifts the focus from being merely a banking product or service offering to a more comprehensive financial services offering including high margin basic insurance products (Becket et al., 2000) by selling both banking and insurance products and services. Through convergence, the choice for clients of financial products and services is larger to choose from and banks can exploit this because they are privy to confidential client information, thereby enabling cross-selling opportunities. As suggested by Auerbach et al. (2012, p. 5), aligning the short- and long-term product needs of clients through, for example the diversified nature of banking products and services, ensures that banks follow the so-called "development agenda" that maximises short-term profit gains with long-term growth. Ensuring a long-term, relationship-based bank-client is therefore vital to ensure this.

A further benefit of cross-selling multiple products and services is that the fixed capacity of a bank is used more efficiently to result in economies of scale and scope (Singhal \& Vij, 2006; Bergendahl, 1995). Economies of scale occur as the size of the organisation increases the "cost of production per unit of output tends to fall," where economies of scope refer to "the combined cost of producing each of these services in one firm are less than the combined cost of producing each of these services through separate firms" (Rose \& Hudgins, 2010, p. 464). An example of this is how insurance companies rely on the distribution networks of banks to widen their client base and reduce distribution and agency costs, whereas banks generate additional revenue streams through the selling of insurance products and services.

\subsection{The Role of Bank Contact-Personnel in Client-Centricity}

The role that contact-personnel play in a client-centric bank-client relationship is vitally important as they deliver the service directly to the client and contribute to creating satisfied and retained clients (Gustaffson, Johnson, 
\& Roos, 2005; Yavas, Benkenstein, \& Stuhldreier, 1997). Yavas (2007, p. 31) argues that contact-personnel are in the best position to assess client evaluations and given this, management must take particular interest of the specific needs of contact personnel (Yavas et al., 1997). This implies that contact-personnel must be empowered to address the needs of clients. As suggested by Kilgore et al. (2005), in addition to having senior management purposefully leading a well-defined client-centric vision and get buy-in from contact-personnel, contact-personnel must be provided with an information technology infrastructure that supports the client-centric vision of the bank. Further to this, Barrutla, Charterina, \& Gilsanz (2009) investigate the effects of empowerment on the performance of bank contact-personnel and empowerment to be a multidimensional construct that has both psychological and process/operational aspects. They distinguish between process-driven and decision-making empowerment citing benefits such as positive attitudes and job satisfaction, organisational commitment, a high propensity to stay with the organisation, improving innovativeness, word-of-mouth communication, job effectiveness, and productivity. Their study finds that of concern is that top management tends to "undermine empowerment" and have personnel that are not aligned to the requirements that empowerment requires. The authors conclude that the relationship between the contact-personnel and client is vital for client satisfaction. This view is supported by Auerbach et al. (2012) who indicate that not only should contact-personnel be empowered through efficient organisational structure and the relevant tools at their disposal, but that they play a key role in ensuring long-term loyalty towards the bank. As Auerbach et al. (2012, p. 12) put it: "It is important that they have the power to implement solutions to the customer's benefit. If this is not the case, there is a danger they will become just an appendage, which could quickly weaken the newly won trust of the customer."

Lavender (2004, p. 291) indicates that contact-personnel should have a strong, proactive sales culture in accordance with client-centric principles that allows information sharing to "understand, own and then maximise client relationships." This further supports the view that contact-personnel must be empowered through processes (or tools) that enable them to identify and address client needs. The notion that client-centricity builds mutually beneficial bank-client relationships is therefore not a simple task, especially given that contact-personnel tend to be poor "listeners" of clients (Bergeron \& Laroche, 2009, p. 7) especially if they are not empowered by the bank with regards to tools they can use. Bergeron \& Laroche (2009) suggest that the ability of contact personnel to listen to clients builds trust, improves service quality, reduces perceived risk, improves client satisfaction, increases repurchase intentions, improves sales performance outcomes and improves word-of-mouth publicity.

In addition to these studies, several have focused on the relational and service quality aspects of bank-client relationships in the South African context. Rootman, Tait, and Bosch (2007) find that a significant relationship exists between the knowledge and attitude of bank employees and the success of customer relationship management strategies adopted within South African banks. The study conducted by Coetzee, van Zyl, and Tait (2013) compare the perceptions of perceived service quality between clients and retail bank branch staff and find that clients tend to be experiencing higher levels of service quality than what bankers perceive them to be. Further to this, the physical layout of the branch and the ability of branch staff to conduct themselves professionally proved very important. Theron, Terblanche, and Boshoff (2008, p. 1005) find that in order to ensure relational commitment, "both the financial service provider and the clients should be willing to invest time and other resources to continue and maintain the relationship." The willingness of the client to remain in the relationship is further dependent on the banks' willingness "to travel the extra mile to maintain the relationship." In a further paper, Theron and Terblanche (2010) establish that competence, relationship benefits, and bonding between bank managers and clients are the most important dimensions in relationship marketing. The paper by Rootman, Tait, and Sharp (2011) investigate the relationship marketing and client retention perceptions of managers in South African banks and find that communication and pricing are vitally important when influencing client relationships. The study ends by posing the question (2011, p. 330): [h] ow can bank managers understand the views of banking clients as well as adapt their banks' strategies to adhere to banking clients' relationship marketing and customer retention needs? This relevance of this question is the basis for this study.

These studies indicate that client-centricity is not merely a process of identifying and addressing client needs. Rather, it is proactive in design and requires consistent engagement with clients by suitably empowered contact-personnel that identify and address ever-changing client needs. Relational and service quality aspects are central to client-centricity, especially if the bank-client relationship is to be built on long-term mutual trust between the parties. In the end, the purpose of being client-centric is to maintain client relationships over a long period of 
time, as they change. As such, this study investigates the perceptions of contact-personnel who are instrumental in facilitating the relationship with clients, and also identifies whether or not they are indeed empowered to be clientcentric.

\section{RESEARCH METHODOLOGY}

\subsection{Sample and Questionnaire Design}

This study was exploratory in nature and had a quantitative design through the usage of a questionnaire to collect data from contact-personnel. The contact-personnel were defined as those that interact directly with clients and specifically included branch managers, tellers, consultants, and enquiries clerks in 37 retail bank branches situated in Bloemfontein, Bethlehem, Kimberley, Kroonstad, and Welkom in central South Africa. Within the 37 retail branches, a total of 674 client-facing contact-personnel are employed by three of the so-called Big Four banks [ABSA, First National Bank (FNB), Nedbank, Standard Bank]. With only three of the Big Four banks willing to participate in this study, ${ }^{1}$ the target population were all of the 674 contact-personnel, thus using a census method of sampling. The questionnaires were personally delivered to each contact-personnel member and collected after two weeks. The overall response rate was high at $83 \%$, indicating that a sample of 559 completed and legible questionnaires were returned and used for data analysis. The response rates for each respective location was $85 \%$ for Bloemfontein, 65\% for Bethlehem, $80 \%$ for Kimberley, $78 \%$ for Kroonstad, and 95\% for Welkom.

The questionnaire was divided into three sections. The first required the contact-personnel to provide their biographical information. Following this, contact-personnel were asked to rank statements determining their perceptions of specific features of a client-centric bank and to what extent they viewed their respective bank as being client-centric. A seven-point Likert scale was used for this question ranging from 'strongly disagree' to 'strongly agree'. The Cronbach Alpha test for reliability for the items in this construct was 0.93 , which is higher than the prescribed minimum cutoff of 0.7 (DeVellis, 2003). Lastly, also using a seven point Likert scale but ranging from 'not important at all' to 'extremely important', the respondents were asked to indicate to what extent their specific bank utilises specific tools typically regarded as contributing to empowering contact-personnel. The Cronbach Alpha for this construct was also good at 0.906. Two focus groups were conducted prior to data collection with randomly selected contact-personnel to test the internal validity of the questions and literature was used as the basis for the items identified in the questionnaire.

\subsection{Data Analysis Methods}

The data analysis is divided into two parts. The first part deals with the specific features of client-centricity and the second part the tools of client-centricity. For both, percentage tables are provided, followed by a cluster and chi-square analysis to identify groups within the contact-personnel. Cluster analysis was applied to group the contact-personnel respondents according to similar response patterns for the respective questions (Hair, Black, Babin, \& Anderson, 2010; Johnson \& Wichem, 2002). In effect, the cluster analysis enables management to identify different segments of contact-personnel who have similar response patterns with regards to the questions posed to them. Before performing the cluster analysis each observation was standardised according to its own mean and standard deviation for the statements posed. This was done to enable cluster analysis to identify response patterns. If this is not done, all the respondents who, for example, answer high on a specific set of statements would be grouped together rather than all of the respondents who answer high relative to their other responses (Hair, Anderson, Tatham, \& Black, 1998, p. 490).

The cluster analysis was applied in two stages. In the first stage, the factor scores were clustered using Ward's hierarchical clustering method (Hair et al., 2010; Johnson \& Wichem, 2002) in order to identify the number of clusters to retain and analyse. Care was taken when identifying the number of clusters. For example, the more clusters chosen, the smaller the number of respondents with the same response patterns in each respective cluster. This diminishes the relevance of each cluster and does not necessarily provide a meaningful explanation of the data. Hair et al. (2010) suggest that the number of clusters used should not be too small, should be significantly different

${ }^{1}$ For confidentiality purposes, the names of these three banks cannot be revealed. 
across the clustering variables and should have theoretical validity. For these reasons, a smaller three-way cluster solution was used. In order to interpret the cluster results more easily, Table I provides the legend for the relative importance the respondents placed on respectively the statements relating to the features and tools of clientcentricity. The values reflecting the relative importance were chosen arbitrarily based on the results varying between approximately -2 and +1 (see Tables III and VI). The purpose of these codes is to provide an easier indication of the relative importance or unimportance that the respective clusters associate with a particular statement. ${ }^{2}$

Table I: Colour Code Legend for Cluster Analysis

\begin{tabular}{l} 
Very important: $\geq 0.8$ \\
Important: $<0.8$ but $>0.2$ \\
Neither important nor unimportant: $\geq-0.2$ but $\leq 0.2$ \\
Unimportant: $>-0.8$ but $<-0.2$ \\
Very unimportant: $\leq-0.8$ \\
\hline
\end{tabular}

A chi-square test (Rice, 1995) was then performed to determine whether or not a significant relationship exists between the three identified clusters and five biographical variables, namely, job title, location, bank, years at the bank, and years in the job position. The cluster analysis and subsequent chi-square test enables bank management to identify specific groups of contact-personnel within their banks and which biographical features have a specific influence within these clusters. This will enable bank management to better understand the behaviour of the contact-personnel and equip them to deal with problems and concerns regarding aspects of client-centricity within the bank.

\section{RESULTS AND ANALYSIS}

\subsection{Results for the Biographical Information}

Table II below provides the biographical data collected. The results indicate that the majority of the respondents were female. Also, there were more whites than blacks within the branches and the majority of the respondents were in the age group 26 to 30 years. Tellers, followed by consultants/bankers, were the most represented contact-personnel with regards to the type of job they did. The majority of respondents were also from Bloemfontein and the respective banks represented are also provided below. The results related to job experience are of particular interest. With regards to the number of years working at the particular bank, $23.61 \%$ of the respondents worked for their bank for between two and five years. The percentage falls to approximately $12 \%$ up until 15 years, and then increases to over $22 \%$ for the period over 15 years. With regards to the number of years in their particular job position, the majority of respondents $(28.09 \%)$ had been working for between one and two years in that position. This gradually peters off to $5.55 \%$ for periods of longer than 15 years.

\footnotetext{
${ }^{2}$ Although the legend in table I indicates "important" or "unimportant", this does not mean that the respective statement is important or unimportant per se, as this would contradict the results in the percentage tables. Rather, these colour codes reflect the importance or unimportant relative to the other responses of the respondent. This distinction forms the basis of understanding a cluster analysis.
} 


\begin{tabular}{|c|c|c|c|c|c|c|c|c|}
\hline Gender & Frequency & $\%$ of total ${ }^{3}$ & Race & Frequency & $\%$ of total & Age & Frequency & $\%$ of total \\
\hline No response & 68 & 12 & No response & 31 & 6 & No response & 31 & 6 \\
\hline Men & 123 & 22 & Asian & 2 & 0 & under 18 & 0 & 0 \\
\hline \multirow[t]{9}{*}{ Female } & 368 & 66 & Black & 188 & 34 & $18-21$ & 11 & 2 \\
\hline & & & Coloured & 127 & 23 & $22-25$ & 112 & 20 \\
\hline & & & Indian & 4 & 1 & $26-30$ & 126 & 23 \\
\hline & & & White & 207 & 37 & $31-35$ & 91 & 16 \\
\hline & & & & & & $36-40$ & 54 & 10 \\
\hline & & & & & & $41-45$ & 57 & 10 \\
\hline & & & & & & $46-50$ & 36 & 6 \\
\hline & & & & & & $51-55$ & 26 & 5 \\
\hline & & & & & & Older than 56 & 15 & 3 \\
\hline Total & 559 & 100 & Total & 559 & 100 & Total & 559 & 100 \\
\hline Job title & Frequency & $\%$ of total & Years at the bank & Frequency & $\%$ of total & Years in job position & Frequency & $\%$ of total \\
\hline No response & 51 & 9 & No response & 30 & 5 & No response & 31 & 6 \\
\hline Manager & 59 & 11 & $<1$ year & 35 & 6 & < 1 year & 103 & 18 \\
\hline Consultant/Banker & 114 & 20 & $1<\mathrm{X} \leq 2$ years & 99 & 18 & $1<\mathrm{X} \leq 2$ years & 157 & 28 \\
\hline Teller & 163 & 29 & $2<X \leq 5$ years & 132 & 24 & $2<X \leq 5$ years & 146 & 26 \\
\hline Enquiries clerk & 78 & 14 & $5<X \leq 10$ years & 71 & 13 & $5<X \leq 10$ years & 65 & 12 \\
\hline \multirow[t]{2}{*}{ Other } & 94 & 17 & $10<X \leq 15$ years & 68 & 12 & $10<\mathrm{X} \leq 15$ years & 26 & 5 \\
\hline & & & $>15$ years & 124 & 22 & $>15$ years & 31 & 6 \\
\hline Total & 559 & 100 & Total & 559 & 100 & Total & 559 & 100 \\
\hline Location & Frequency & $\%$ of total & Bank & Frequency & $\%$ of total & & & \\
\hline No response & -- & -- & No response & -- & -- & & & \\
\hline Bloemfontein & 246 & 44 & Bank A & 209 & 37 & & & \\
\hline Bethlehem & 43 & 8 & Bank B & 201 & 36 & & & \\
\hline Kimberley & 109 & 19 & Bank C & 149 & 27 & & & \\
\hline Kroonstad & 50 & 9 & & & & & & \\
\hline Welkom & 111 & 20 & & & & & & \\
\hline Total & 559 & 100 & Total & 559 & 100 & & & \\
\hline
\end{tabular}

${ }^{3}$ All the percentages are rounded off to the nearest whole number. 
These results indicate an important feature of the employment tendencies within central South Africa. Given that this region is not regarded as the financial and economic hub of South Africa, in many cases it serves as a platform for bankers to launch rather than pursue a career. In other words, instead of staying in cities or town such as those in the smaller provinces in central South Africa, many bankers eventually migrate to head offices that are situated predominantly in Gauteng (Johannesburg or Pretoria) or the Western Cape (Cape Town). As one branch manager put it "you either work here for a very short period of time and move to Gauteng, or you stay here for the rest of your life." The results from the biographical information in Table II seem to suggest, therefore, that this does appear to be the case. A further possible reason, especially given that the majority of the contact-personnel have been working in their respective position for less than five years, is that given that professionals in general do not typically pursue careers in central South Africa, they are forced to cross-skill and rotate their jobs continually given the constant staff turnaround. Anecdotal evidence based on informal conversations with the contact-personnel suggested this was indeed the case and served as a method branch managers used to ensure that branch personnel were multi-skilled when it came to the inner operational workings of the branch.

\subsection{Results for the Features of Client-Centricity}

The percentage tables for the perceptions of the contact-personnel regarding the features of client-centricity within their respective branches are provided below in Table III. As is evidenced, the bankers mostly agree or strongly agree with the statements. The statements that ranked most highly relate to the emphasis management places on service delivery in the branch, the emphasis management places on identifying the needs of clients, and the products and services offered by the bank addressing the needs of clients. The contact-personnel therefore acknowledge that the most important aspects of client-centricity are the clear emphasis management places on service quality, the needs of clients and products and services that address the needs of clients. Given that all the statements were ranked highly, this does not however imply that the other statements are unimportant, but rather less important. These results warrant the cluster analysis as it identifies the relative importance and unimportance of respondents as they are grouped in their respective clusters.

Table III ${ }^{5}$ : Features of Client-Centricity for Banks

\begin{tabular}{|c|c|c|c|c|c|c|c|}
\hline Statement & $\begin{array}{l}\text { Strongly } \\
\text { Disagree }\end{array}$ & Disagree & $\begin{array}{l}\text { Slightly } \\
\text { Disagree }\end{array}$ & $\begin{array}{l}\text { Neutral } \\
\text { Opinion }\end{array}$ & $\begin{array}{c}\text { Slightly } \\
\text { Agree }\end{array}$ & Agree & $\begin{array}{c}\text { Strongly } \\
\text { Agree }\end{array}$ \\
\hline $\begin{array}{l}\text { Your bank trains you well enough to identify the needs } \\
\text { of your clients. (A1) }\end{array}$ & 1.25 & 1.43 & 2.33 & 6.26 & 11.63 & 40.07 & 34.7 \\
\hline $\begin{array}{l}\text { Your bank trains you well enough to address/meet the } \\
\text { needs of your clients. (A2) }\end{array}$ & 0.89 & 1.43 & 2.5 & 5.72 & 13.95 & 40.61 & 32.74 \\
\hline $\begin{array}{l}\text { Your management emphasises the importance of } \\
\text { improving the service delivery process in branches. (A3) }\end{array}$ & 0.89 & 0.54 & 1.07 & 5.55 & 9.84 & 39.53 & 40.79 \\
\hline $\begin{array}{l}\text { Your management encourages you to make suggestions } \\
\text { regarding innovative new ideas or improving service } \\
\text { delivery processes in the branch. (A4) }\end{array}$ & 1.25 & 0.89 & 2.15 & 7.87 & 12.16 & 39 & 35.06 \\
\hline $\begin{array}{l}\text { Your management places emphasis on identifying the } \\
\text { needs of your clients. (A5) }\end{array}$ & 0.54 & 0.18 & 1.43 & 5.72 & 11.45 & 42.22 & 36.49 \\
\hline $\begin{array}{l}\text { Your bank's management empowers you to be able to } \\
\text { address the needs of your clients. (A6) }\end{array}$ & 1.07 & 0.54 & 2.15 & 7.69 & 13.24 & 40.61 & 32.38 \\
\hline You have up-to-date information about your clients. (A7) & 0.36 & 0.89 & 3.58 & 10.73 & 17.71 & 37.21 & 27.55 \\
\hline $\begin{array}{l}\text { The products and services offered by your bank address } \\
\text { the needs of your clients. (A } 8 \text { ) }\end{array}$ & 0.36 & 0.36 & 1.25 & 7.16 & 12.34 & 41.32 & 35.06 \\
\hline $\begin{array}{l}\text { The expectations that clients of your bank have about } \\
\text { service is realistic. (A9) }\end{array}$ & 1.07 & 0.36 & 2.68 & 10.55 & 16.64 & 38.46 & 26.48 \\
\hline $\begin{array}{l}\text { The expectations that clients of your bank have about } \\
\text { their banking products are realistic. (A10) }\end{array}$ & 3.4 & 1.97 & 3.58 & 11.63 & 18.96 & 37.21 & 17.53 \\
\hline
\end{tabular}

A cluster analysis was conducted in order to group the respondents according to specific responses and in so doing, identify specific groups of contact-personnel within the banks. This was done for both the features (Table

\footnotetext{
${ }^{4}$ Based on a personal conversation between the researcher and a branch manager in Bethlehem.

${ }^{5}$ Please note that the rows in the following tables do not necessarily add-up to $100 \%$ of the responses. If that is the case, the missing percentage pertains to respondents who did not answer the respective question.
} 
IV) and tools (Table VI) of client-centricity. The three-way cluster solutions for the features of client-centricty are provided in Table IV.

Table IV: Cluster Means Results for Features of Client-Centricity

\begin{tabular}{lcccccccccccc}
\hline Cluster & Frequency & $\mathbf{A 1}$ & $\mathbf{A 2}$ & $\mathbf{A 3}$ & $\mathbf{A 4}$ & $\mathbf{A 5}$ & $\mathbf{A 6}$ & $\mathbf{A 7}$ & $\mathbf{A 8}$ & $\mathbf{A 9}$ & $\mathbf{A 1 0}$ \\
\hline $\mathbf{1}$ & 145 & -0.43 & -0.41 & 0.32 & -0.35 & 0.01 & -0.32 & 0.11 & 0.39 & 0.38 & 0.30 \\
$\mathbf{2}$ & 153 & 0.26 & 0.29 & 0.33 & 0.20 & 0.33 & 0.40 & 0.34 & 0.39 & -0.31 & -2.23 \\
$\mathbf{3}$ & 153 & 0.50 & 0.35 & 0.48 & 0.42 & 0.47 & 0.12 & -1.20 & -0.18 & -0.61 & -0.34 \\
\hline
\end{tabular}

The three-way cluster solution for the features of client-centricity is as follows:

\section{Cluster 1}

Cluster 1 is characterised by a general feeling amongst contact-personnel that their banks do not train and empower them to be able to identify and address the needs of their clients (A1, A2, and A4 are considered relatively unimportant). They also feel that their banks do not encourage them to be innovative to improve service delivery in the branch set-up (A4). This cluster is therefore characterised by their relatively negative feelings towards their banks vis-à-vis the empowerment by management to do their jobs effectively.

\section{Cluster 2}

Relatively speaking, the respondents in cluster 2 are in general satisfied that their banks empower them to be client-centric (A1 to A8 are ranked as relatively more important). However, they feel that given this generally positive view, their clients do not have realistic expectations of service and banking products and services offered by the bank (A9 and A10). This is especially so with regards to the expectations clients have regarding the products offered by the bank. This might suggest that clients are not suitably informed about the workings of the products, or alternatively, that the contact-personnel offer products to clients that they either do not need or find useful. This result might further imply that contact-personnel are not empowered or trained to address client needs with suitable products.

\section{Cluster 3}

The contact-personnel within cluster 3 indicate that they are satisfied with the ability and awareness of service-related issues that their bank provides them with (items A1 to A6). What differentiates this cluster from the other two is that the contact-personnel within it regard the information the bank has of clients as not being up-to-date (statement A7). This, coupled with the result that perception that the products and services offered to clients are not necessarily realistic, seems to suggest that the contact-personnel might find that more cross-selling could occur if the bank has more up-to-date client information. Therefore, although contact-personnel feel that they are suitably trained and empowered to address the needs of their clients (A1 and A2), they feel that the bank does not provide up-to-date information about clients. This could of course also imply that clients do not provide the bank with up-todate information.

The colour codes identified in Table IV indicate that only statements A3 and A5 are regarded as relatively important for all three clusters. A3 refers to the importance management places on improving service quality in the branch and A5 the importance management places on identifying the needs of clients. This result indicates that contact-personnel are acutely aware of the importance of constantly seeking to improve service quality and addressing client needs. The message management is trying to delineate to contact-personnel regarding service quality and client needs therefore appears to being communicated effectively to contact-personnel. Given the results of the cluster analysis in general though, the message from management to be more client-centric is not necessarily being complemented with being empowered to being client-centric. These results are inferred from the differences in the three clusters.

In order to determine whether or not the three clusters identified are associated with specific biographical characteristics of the contact-personnel, chi-square tests were conducted. The results of this are presented in Table V. 
Table V: Chi-Square Results for Features of Client-Centricity

\begin{tabular}{lccc}
\hline \multicolumn{1}{c}{ Biographical Variable } & Df & Value & Prob \\
\hline Job title & 8 & 15.73 & 0.05 \\
Location & 8 & 4.84 & 0.77 \\
Bank & 4 & 1.34 & 0.85 \\
Years at the bank & 8 & 8.01 & 0.43 \\
Years in job position & 8 & 3.52 & 0.90 \\
\hline
\end{tabular}

Only the job title of contact-personnel is found to be statistically significant at the 0.1 level. This means that only the jobs of the specific contact-personnel have a relationship with the three clusters identified, implying that when the three clusters are used as a method to identify whether or not banks are client-centric, the specific jobs of the contact-personnel must be taken into account. Therefore, given that the remaining chi-square tests returned statistically insignificant results indicates that the perceptions by contact-personnel of whether or not a bank is client-centric does not matter where the branch is, what bank it is, or how long the contact-personnel member has worked at the bank or in their respective position. Management must therefore keep in mind that when they formulate policies based on perceptions of client-centricity within the bank, they need to take particular notice of specific job functions within the branch, and perhaps more importantly, what the views of these respective people executing the functions are. Once again, however, this does not imply that the other biographical features are not important, but rather less important.

\subsection{Results for Tools of Client-Centricity}

The contact-personnel were further asked to rank the importance of several tools or mechanisms that the literature regards as promoting client-centricity. The results are provided in Table VI.

Table VI: Specific Tools of Client-Centricity

\begin{tabular}{|c|c|c|c|c|c|c|c|}
\hline Statement & $\begin{array}{l}\text { Not important } \\
\text { at all }\end{array}$ & $\begin{array}{c}\text { Not } \\
\text { important }\end{array}$ & $\begin{array}{l}\text { Slightly not } \\
\text { important }\end{array}$ & $\begin{array}{l}\text { Neutral } \\
\text { opinion }\end{array}$ & $\begin{array}{c}\text { Slightly } \\
\text { important }\end{array}$ & Important & $\begin{array}{l}\text { Extremely } \\
\text { important }\end{array}$ \\
\hline $\begin{array}{l}\text { Computer systems/programmes that } \\
\text { better assist you to help clients. (B1) }\end{array}$ & 0.54 & 1.43 & 2.15 & 10.55 & 10.91 & 25.22 & 46.51 \\
\hline Support from your line manager. (B2) & 1.25 & 1.43 & 1.97 & 8.77 & 12.88 & 30.41 & 40.79 \\
\hline $\begin{array}{l}\text { Support from your regional manager. } \\
\text { (B3) }\end{array}$ & 2.33 & 1.43 & 4.11 & 12.52 & 14.49 & 30.95 & 31.31 \\
\hline $\begin{array}{l}\text { Support from operations/ } \\
\text { administrative/ back-office staff } \\
\text { members. (B4) }\end{array}$ & 1.07 & 1.25 & 2.68 & 9.3 & 12.88 & 31.13 & 38.82 \\
\hline $\begin{array}{l}\text { More realistic and achievable Key } \\
\text { Performance Indicators (KPIs) or } \\
\text { targets on your performance appraisal. } \\
\text { (B5) }\end{array}$ & 1.97 & 0.89 & 4.29 & 11.81 & 18.43 & 30.95 & 28.09 \\
\hline $\begin{array}{l}\text { Easier to follow and/or better defined } \\
\text { internal processes. (B6) }\end{array}$ & 0.54 & 1.79 & 1.97 & 10.73 & 16.99 & 37.39 & 26.12 \\
\hline $\begin{array}{l}\text { More staff members that can assist } \\
\text { clients. (B7) }\end{array}$ & 2.33 & 1.79 & 1.79 & 8.05 & 15.92 & 33.45 & 32.74 \\
\hline $\begin{array}{l}\text { Up-to-date client information on the } \\
\text { bank database. (B8) }\end{array}$ & 1.07 & 0.72 & 2.68 & 9.12 & 15.21 & 33.63 & 32.92 \\
\hline $\begin{array}{l}\text { An assistant to help you with the paper } \\
\text { work and general administration. (B9) }\end{array}$ & 5.37 & 2.5 & 3.76 & 12.16 & 15.92 & 27.73 & 27.19 \\
\hline
\end{tabular}

All the tools were regarded as being important or extremely important. The three highest ranked scores were the computer systems and programmes that better assist to help clients (B1), the support from the line manager (B2), and the support from operational or back-office staff members (B4). The respondents were further asked to provide alternative tools they feel as being important that were not listed in the questionnaire. Of these alternatives, the most common related to "more training," "regular software updates," "standard forms," "less bank processes," "quicker turnaround time for approvals," "more open-mindedness in credit departments," "televisions for more information," "no temporary staff," and "everyone wants the branch to just do [what it is supposed to do] with no assistance." These reasons indicate the frustrations of contact-personnel with regards to the inefficiencies in the operational environment within the branch. 
In order to group these responses regarding tools of client-centricity into groups, a cluster analysis was conducted and is reflected in Table VI.

Table VI: Cluster Means for Tools of Client-Centricity

\begin{tabular}{lcccccccccc}
\hline Cluster & Frequency & B1 & B2 & B3 & B4 & B5 & B6 & B7 & B8 & B9 \\
\hline $\mathbf{1}$ & 191 & 0.66 & 0.65 & 0.28 & 0.49 & -0.06 & -0.08 & -0.41 & -0.19 & -1.34 \\
$\mathbf{2}$ & 119 & -0.32 & 0.36 & 0.25 & 0.49 & -1.03 & -0.47 & 0.05 & 0.24 & 0.43 \\
$\mathbf{3}$ & 122 & 0.41 & -0.48 & -1.04 & -0.53 & 0.19 & 0.22 & 0.61 & 0.36 & 0.27 \\
\hline
\end{tabular}

\section{Cluster 1}

Cluster one is the largest of the three clusters and is characterised by the relative unimportance of item B9 in particular. This cluster, therefore, does not regard support staff in the sales process as that important (B7 and B9), especially with regards to relieving the administrative burden. They do however regard computer systems, line manager support, regional manager support, and back-office support as important (B1 to B4).

\section{Cluster 2}

Respondents in cluster two do not regard computer systems (B1), well-defined internal processes (B6), and in particular realistic key performance indicators/targets (B5) as important tools relative to the other items when being client-centric.

\section{Cluster 3}

The results for cluster three indicate a negative feeling towards management of any kind (B2 and B3) as well as any support from the administrative back-office staff (B4). Due to the relative importance placed on B1, B6, B7, B8, and B9, these contact-personnel seem to place heavy emphasis on being empowered to conduct their job efficiently and specifically so in the sales process when they are dealing directly with clients.

Considering the colour codes of Table VI, two tools (B1 and B8) in particular seem to be considered by all three clusters as important, albeit to a slightly lesser degree ( -0.19 for cluster 1 on statement B8 and -0.32 for cluster 2 on statement B1). Both of these refer to the information the banks have on clients and the computer systems the banks have in place to manage that information. Conversely, the statements found to be relatively less important relate to the KPIs on performance appraisals (B5) and to a slightly lesser extent, internal policies that are better defined or easier to follow (B6). The results suggest that contact-personnel feel that KPIs that are linked to performance do not necessarily result in the bank being client-centric. Rather, as the results from the cluster analysis further indicate, empowering the contact-personnel with suitable administrative and technological support is more important. Furthermore, the result of statement B6 suggests that there is an understanding amongst contactpersonnel that the internal processes within the bank are inherently complex. This might be acknowledgment amongst contact-personnel that bank processes need to reflect risk mitigating steps and adhere to strict levels of governance. Also, the findings suggest that being client-centric is a 'hands-on' process - if contact-personnel are not suitably empowered to address client needs there and then, its effectiveness as a strategy fails.

Table VII provides the chi-square results for selected biographical variables by cluster for the tools used to promote client-centricity.

Table VII: Chi-Square Results for Tools of Client-Centricity

\begin{tabular}{lccc}
\hline \multicolumn{1}{c}{ Biographical Variable } & Df & Value & Prob \\
\hline Job title & 8 & 2.16 & 0.98 \\
Location & 8 & 10.45 & 0.23 \\
Bank & 4 & 6.29 & 0.18 \\
Years at the bank & 8 & 11.24 & 0.19 \\
Years in job position & 8 & 14.58 & 0.07 \\
\hline
\end{tabular}


The results indicate that the number of years a bank employee has worked in a specific position is the only demographic variable that has a statistically significant relationship with the three clusters. In other words, within the three identified clusters only the number of years that the contact-personnel have worked in a particular job position is found to have any particular relationship with the clusters. This means that if management want to implement policies that relate to improving the tools of client-centricity, on-the-job experience of contact-personnel must be an integral aspect of how they approach it. This result suggests that contact-personnel who have more job experience are more likely to rate specific tools of client-centricity as more or less important. This makes sense as they have more experience and for a longer period of time with regards to using these tools.

\section{DISCUSSION AND RECOMMENDATIONS}

The results of the features of client-centricity within the banks and the tools required to be client-centric are found to be positive. There are however also certain areas of concern. The findings of these are discussed in the following section.

\subsection{The Features of Client-Centricity}

The features of client-centricity refer to what aspects of client-centricity the contact-personnel perceive their respective banks to have. The major findings are:

- $\quad$ Top management is very clear to highlight (to contact-personnel) the importance of offering superior service quality and addressing the banking needs of clients through relevant products and services.

- The job title of contact-personnel is the most important demographic variable that reflects a relationship, and thus has an effect, on the percieved level of client-centricity within a bank.

- $\quad$ Neither the location of contact-personnel, which bank they work for, how long they have worked at the bank, nor the number of years in their respective job position was found to have a significant statistical relationship with identifying whether or not a bank is client-centric.

These results seem to suggest that contact-personnel place a larger emphasis on being provided with managerial support than having well-defined (administrative) processes in place that deliver the support function. The most likely reason for this is that contact-personnel perform a sales-and-service function rather than an administrative function. This does not however imply that contact-personnel do not regard internal processes as important. Rather, the results suggest that contact-personnel want to be empowered to address client needs at the point of engagement and fulfil the sales and service function first and foremost, rather than worry about the processes that follow from an administrative point of view. This administrative function must be fulfilled by the back-office and/or support staff and complement the sales and services function of the contact-personnel. In view of the sales-and-service and administrative function being decentralised in branches, the results indicate that this policy is the correct one to adopt, on condition that contact-personnel are allowed to engage with clients in a sales-and service context rather than an administrative context.

Regarding the features of client-centricity, three clusters (or groups) hold distinctly different views of what a client-centric bank means to them. The first group feels that they are not empowered to be client-centric and especially with regards to being provided with the necessary training and development. It is proposed that bank management ensure that contact-personnel are put through rigorous training and development programmes that empower them to conduct their jobs more effectively.

The second group of contact-personnel feel that they are adequately empowered and trained, but feel that client expectations especially regarding bank products and services are unrealistic. This might suggest that banks are creating expectations with clients (through their advertising and marketing campaigns) that cannot be met by the contact-personnel who inevitably engage with the clients. The fact that this group of contact-personnel also feel that management does not always encourage them to make suggestions to improve delivery processes also seems to suggest that there might be conflict, or at least differences between contact-personnel and management within the branch. It is proposed therefore that bank management must ensure at all times that expectations made to the public through advertising must be aligned to the capacity of branches and specifically contact-personnel to deliver on 
those expectations. If this is not the case, it creates a sure-fire situation where clients are dissatisfied due to their expectations not being met. In turn, this dissatisfaction is projected onto contact-personnel as they engage with clients. Vertical communication between top management and contact-personnel via branch management is vital to ensure that these unrealistic client expectations are, if not avoided, at least managed.

The third group of contact-personnel are characterised by their feelings towards specifically clients - they feel that client information is not up-to-date and that client expectations of service quality and products and services are not necessarily realistic. A lack of up-to-date client information could be due to clients not informing the bank of changes in their personal information. It is proposed that the management in a branch provides clients with in-store self-service banking facilities that are easy to use with instructions on usage must be readily available (supported by Krishnan et al., 1999). In addition to alleviating the pressure on contact-personnel to constantly ask clients whether or not their information is up-to-date, it will ensure that the bank has information that is more accurate from which it can identify cross-selling opportunities.

Furthermore, as with cluster two, there might be poor alignment between what a respective bank portrays to the public and what the bank does to empower contact-personnel. However, this cluster feels that they are trained, but not necessarily always empowered. Anecdotal evidence at one bank in particular indicated that on several occasions a marketing campaign would be launched through the national media over a weekend only for the branch to be formally informed of the campaign the following Monday morning. This was said to be particularly the case in the smaller branches in the smaller towns. A possible problem is therefore not necessarily that contact-personnel are not empowered, but that they are given too little time to react to client expectations. Once again, vertical communication from top management must not only be ensured, but must be done speedily and concisely so that contact-personnel are able to address client queries.

The job title of contact-personnel is the only demographic variable found to have any relationship with the three cluster groups. This implies that what type of job function contact-personnel have has a significant relationship with identifying important features of client-centricity. This finding further suggests that if bank management want to identify features of client-centricity that it, for example, wants to implement in the organisation, it must engage rather with a group of, say, tellers or consultants, than, for example, senior staff. Job function therefore appears more important than seniority with regards to establishing what features constitute a client-centric bank. This finding appears to be the case with all the banks surveyed in the study. It is therefore proposed that there is more value in identifying whether or not the bank is implementing client-centric principles if this is justified according to job function as opposed to, say, job experience. Given the operational model used by bank branches with regards to splitting sales-and-service and administrative functions, this finding implies that contact-personnel are committed to their role within this operational model.

\subsection{The Tools of Client-Centricity}

The tools of client-centricity refer to the tools contact-personnel are provided with to enable them to provide a client-centric experience to clients. The major findings were:

- The most important tools contact-personnel regard as being essential to promoting client-centricity are related to offering functional support: computer and software packages that address client needs, up-to-date client information, line manager support, and operational (or back-office) support.

- The least important tool contact-personnel regard as important for client-centricity are realistic and achievable KPIs and performance targets on their respective performance appraisals, as well as better defined internal (administrative-based) processes.

- The most experienced contact-personnel have the most significant impact to identifing the importance of tools that promote client-centricity.

As with the findings on the features of client-centricity, these findings suggest that contact-personnel regard tools that contribute to functional support as most important in the client-centric context. This functional support is delineated especially along administrative lines related to technology, line-management, and back-office support, as opposed to the actual administrive burden that is paperwork or compliance driven. These results suggest that these 
contact-personnel are probably more self-motivated and hands-on with regards to operational issues, but regard the sales process as being more important than the actual administrative process when considering client-centricity.

As with the features of client-centricity, three cluster groupings were identified. Group one appears to be a group that is autonomous in their working environment and rely on the ability of the bank to empower them through the technology and support they receive from line management. This group is the largest of the three groups and appear to be more hands-on in the sales-and service process required from contact-personnel in the branch environment. Group two is characterised according to the lack of importance they place on technology to empower them and appear to rely more on ensuring they are empowered through suitable operational efficiencies that support the sales process from the sales orientated front-office to the administrative-orientated back-office. This cluster is therefore characterised as not necessarily being more hands-on as cluster one is, but rather tend to place more importance on having support from the operational (administrative) side of the bank.

The third group is defined according to their somewhat negative feelings towards management within the client-centric context. In particular, this group feels that there is lack of support from the line and regional manager. This is problematic as senior management ensure that lower level employees (in this case the contact-personnel) are communicated to with regards to the strategy and direction of the bank. Based on this finding, it is proposed that management (whether line or regional) make a concerted effort to ensure that they provide the required support to contact-personnel. However, given the composition of this cluster, the contact-personnel appear to place more emphasis on ensuring that they get the job done, than who supports them in the direct process of getting the job done. Put differently, the contact-personnel in cluster three regard operational efficiency and support as more important than who supports them per se. Once again therefore (as with the first two clusters) there appears to be a clear tendency of the contact-personnel to prefer client-centric tools that empower them to be hands-on in sales-andservice engagement process with clients. The results further suggest that contact-personnel in general appear to be self-starters and that whilst they function within the sales-and-service environment, they prefer tools that empower them to do their work better whilst engaging with clients. This finding is consistent with the proposals made Auerbach et al. (2012), Selden (2007), Rootman et al. (2007), and Selden and MacMillan (2006) with regards to establishing an organisational culture conducive to being client-centric.

Although not explicitly in all three clusters, the computer and software packages that contact-personnel have at their disposable as well as up-to-date client information are considered to be relatively more important when compared to the other client-centric tools. These are of the most important drivers of client-centricity identified in the literature by Dohmen et al. (2009), Selden (2007), and Kilgore et al. (2005) and compliments the banks' ability to collect, store, and disseminate proprietary client information. The chi-square test further reveals that the on the job years of experience is the only variable that has a significant relationship with identifying the most important tools of client-centricity. This implies that that when management wants to assess the importance (and relevance) of a particular tool they want to implement to enhance client-centricity, they should consult contact-personnel that have more years of experience in a specific position. This finding suggests that staff expertise and experience are vitally important when assessing the importance of client-centric interventions from a management point of view.

\subsection{Recommendations}

Given the findings of this study, the challenge for contact-personnel is that the bancassurance model adopted by banks is not an easy model to adopt because, as Staikouras (2006, p. 134) suggests, the cultures of insurance and bank employees are distinctly different: "Insurance is associated with marketing innovation, consultative selling and incentive compensation. On the other hand, commercial banking culture is one of relationship building, little risk, stability and compensation schemes are less related to performance." In order to address these 'diverging' cultures and simultaneously ensure that the bank adopts client-centric principles, there must be a concerted effort from all managers throughout the organisation to manage the effectiveness of contactpersonnel when dealing with clients.

The findings clearly indicate that in most part, the contact-personnel regard their banks as being clientcentric, but that there are concerns with regards to the support they receive to facilitate the process of transactions via functional support staff. This is clearly a management problem that can be addressed by allocating resources to the sales process. Further to this, branch managers must support their contact-personnel in the sales process. This 
implies that contact-personnel must feel at liberty to provide feedback to management of pending and current issues or concerns they have. Communication between contact-personnel and management is therefore essential to ensure that cognisance is taken of what is happening in the branch with regards to client interactions (see Ernst \& Young, 2012 and Rootman et al., 2011). Communication should be upward from contact-personnel to management as well as downward from management to contact-personnel. It does not help if communication is only horizontal at branch level because the decision-making abilities affecting strategy are driven by senior management and input from contact-personnel must be mandatory to have an effective client-centric strategy. Central to the empowerment of contact-personnel is that the processes they follow must receive the necessary support from management, backoffice personnel, and the processes and technology that facilitate the sales process. This will ensure that fragmented business units and bank systems that serve the client are suitably managed, controlled and market-orientated (Kaplan \& Norton, 2006; Seldon \& MacMillan, 2006; Hedley et al., 2005; Trethowan \& Scullion, 1997). Open lines of communication must exist between contact-personnel and senior bank management. By empowering contactpersonnel to better address the needs of clients, they will become more client-centric in focus.

\section{LIMITATIONS AND AREAS FOR FURTHER RESEARCH}

This study was conducted in central South Africa which is not a major metropolitan and financial hub of the South African economy. As such, although the findings of the paper may be generalisable to branches that operate in smaller rural-based environments, it may not be to those operating in large metropolitan-based cities. The nature of relationships in these metropolitan hubs are generally characterised by having clients that are more technologically savvy and thus more dependent on electronic banking facilities. The face-to-face (or physical contact) dynamic is therefore different to those of a more rural-based environment where it is a lot easier to visit the branch. Further to this, future research should focus on extending to branches not only operating in large urban cities, but also to different divisions within the bank, such as commercial or corporate banking. This implies that future studies do not have to be limited to only the branch environment given that corporate bankers, for example, typically operate from regional or head office buildings. The nature of client-centric operations within a branch environment would therefore be different based on the nature of the bank-client relationship and the (socioeconomic) environment within which the bank and client respectively function. This warrants further investigation.

\section{CONCLUSIONS}

A client-centric bank is one that is proactive to identify and address the ever-changing needs of clients as they change. With banks constantly vying for increased market share in an extremely competitive and informationrich economic environment, a client-centric strategy capitalises on the ability of banks to offer comprehensive financial services offerings rather than traditional banking-only services. Because banks perform an intermediation function and collect proprietary client information, client-centricity presupposes that it is not the collection of this information that is important per se, but rather the usage of the information. At the forefront of this client-centricity approach are contact-personnel in bank branches who engage directly with clients. They are the first port-of-call when engaging with the bank and play a vital role in formulating client perceptions of a particular bank. These contact-personnel therefore need to be empowered to not only identify client needs, but address them timeously. Ideally, this must be done in a proactive manner where contact-personnel offer solutions to clients based on the information they have and in so doing cross-sell products and services to clients that address their needs and enhance bank profitability.

Given the results of this study, a client-centric bank is one that is proactive with proprietary client information to cross-sell additional products and services, whilst at the same time ensuring that contact-personnel are empowered to identify and address client needs at the point of engagement. This must all be done within an environment that supports the sales-and-services function of contact-personnel through well-defined and complementary administrative functions. The findings of this study reveal that contact-personnel in general regard their respective banks to be client-centric. Where concerns do exist for contact-personnel, they relate mostly to a lack of functional support from management and administrative departments. Specific job descriptions were also found to be the most likely factor to identify client-centric features in a bank. Similarly, the number of years of experience contact-personnel have was found to be the most likely factor that identifies the most important tools used to enhance client-centricity. 
This study therefore makes a contribution to the notion of client-centricity within the South African retail banking sector. Not only is it the first paper of its kind in this context, but it is also the first to be conducted amongst contact-personnel in the central South African region. Its contribution is that contact-personnel in general view their respective banks to be client-centric, but feel that the support offered by in particular management and administrative staff does not enhance the client-centric principles the bank attempts to achieve. Given that banks are competing for retail clients in a highly competitive, albeit concentrated South African banking sector, these are issues that needs to be addressed in order to be client-centric.

\section{AUTHOR INFORMATION}

Dr. Johan Coetzee is a senior lecturer at the Department of Economics and Business School at the University of the Free State in South Africa. He has published in both local and international journals in topics focusing on bank/client relationships and specialises in bank management and specifically the management of risk by banks. He is a visiting senior lecturer in banking at the Salzburg University of Applied Sciences in Austria and is currently an external board member for the Milpark Banking School and a consultant in bank risk management to the South African Reserve Bank College in Pretoria. E-mail: $\underline{\text { CoetzJ@ufs.ac.za }}$

\section{REFERENCES}

1. Artikis, P. A., Mutenga, S., \& Staikouras, S. K. (2008). A practical approach to blend insurance in the banking network. The Journal of Risk Finance, 9(2), 106-124.

2. Auerbach, P., Argimon, R. F., Hieronimus, F., Roland, C., \& Teschke, B. (2012). Banking on customer centricity: Transforming banks into customer-centric organizations, EMEA Banking Practice, McKinsey \& Company, Inc, April.

3. Bergendahl, G. (1995). The profitability of bancassurance for European banks. International Journal of Bank Marketing, 13(1), 17-28.

4. Barrutla, J. M., Charterina, J., \& Gilsanz, A. (2009). Salesperson empowerment in Spanish banks: A performance-driven view. Journal of Financial Services Marketing, 14(1), 40-55.

5. Band, W., \& Guaspari, J. (2003). Creating the customer-engaged organization. Marketing Management, 12(4), 34-39.

6. Bergeron, J., \& Laroche, M. (2009). The effects of perceived salesperson listening effectiveness in the financial industry. Journal of Financial Services Marketing, 14(1), 6-25.

7. Bogaerts, E. (2011). The 4 C's of Core Banking. Journal of Internet Banking and Commerce, 16(1), 1-4.

8. Coetzee, J. (2009). Personal or remote interaction? Banking the unbanked in South Africa. South African Journal of Economic and Management Sciences, 12(4), 448-460.

9. Coetzee, J. van Zyl, H., \& Tait, M. (2013). Perceptions of service quality by clients and contact-personnel in the South African retail banking sector, Southern African Business Review, 17(1), 1-22.

10. Devlin, J. F. (2000). Adding value to retail financial services. International Journal of Bank Marketing, 18(5), 222-232.

11. Devlin, J. F., \& Gerrard, P. (2004). Choice criteria in retail banking: An analysis of trends. Journal of Strategic Marketing, 12(1), 13-27.

12. DeVellis, R. F. (2003). Scale development: Theory and applications (2nd Ed.). Thousand Oaks, California: Sage.

13. Dohmen, A., Moorman, J., \& Rosemann, M. (2009). Using a smartphone application for customer centric banking. ACIS 2009 Proceedings. Paper 67. Retrieved 6 January 2013 from http://aisel.aisnet.org/acis2009/67

14. Ernst \& Young. (2012). The customer takes control: Global Consumer Banking Survey 2012, EY Global Banking \& Capital Markets Center. Retrieved 11 April 2014 from http://www.ey.com/Publication/ vwLUAssets/Global_Consumer_Banking_Survey_2012_The_customer_takes_control/\$FILE/Global_Cons umer_Banking_Survey_2012.pdf

15. Ernst \& Young. (2014). Winning through customer experience: EY Global Consumer Banking Survey, EY Global Banking \& Capital Markets Center. Retrieved 11 April 2014 from http://www.ey.com/GL/en/ Industries/Financial-Services/Banking---Capital-Markets/Global-consumer-banking-survey-2014 
16. Florin-Mihai, M. (2013). The implications of marketing activity in risk analysis, core element of lending policy to commercial banks. Annals of the „Constantin Brâncuşi” University of TârguJiu, Economy Series, 2, 186-196.

17. Hair, J. F., Anderson, R. E., Tatham, R. L., \& Black, W. C. (1998). Multivariate data analysis (5th ed.). Prentice-Hall: USA.

18. Gustafsson, A., Johnson, M. D., \& Roos, I. (2005). The effects of customer satisfaction, relationship commitment dimensions, and triggers on customer retention. Journal of Marketing, 69(3), 210-218.

19. Hair, J. F., Black, W. C., Babin, B. J., \& Anderson, R. E. (2010). Multivariate data analysis: A global perspective. Pearson Prentice-Hall: USA.

20. Hedley, K., White, J., Petit, C., \& Banerjea, S. (2005). The paradox of banking 2015: Achieving more by doing less. IBM Institute for Business Value. Retrieved 13 April 2012 from www.935.ibm.com/ services/multimedia/cn_zh_2015_banking_en.pdf

21. Hislop, A., Peterson, O., \& Ziegler, R. (2002). Making bancassurance really work: From product-oriented cross-selling to customer-focused cross-buying. IBM Business Consulting Services. Retrieved $29 \mathrm{March}$ 2012 from www.ibm.com

22. Johnson, R. A., \& Wichem, D. W. (2002). Applied multivariate statistical analysis (5 ${ }^{\text {th }}$ ed.). Prentice-Hall: USA.

23. Kilgore, T., Kolatch, B., \& Colbeck, P. (2005). Loyalty quest: Enhancing the retail banking experience to drive growth, Deloitte \& Touche and Consumer Banker Association, December, no.5167.

24. Lavender, M. (2004). Maximising customer relationships and minimising business risk. International Journal of Bank Marketing, 22(4), 291-296.

25. Lymberopoulos, K., Chaniotakis, I. E., \& Soureli, M. (2004). Opportunities for banks to cross-sell insurance products in Greece. Journal of Financial Services Marketing, 9(1), 34-48.

26. Nayyar, P. R. (1990). Information asymmetries: a source of competitive advantage for diversified service firms. Strategic Management Journal, 11(7), 513-519.

27. Okeahalam, C. C. (2008). Does bancassurance reduce the price of financial service products? Journal of Financial Services Research, 33(3), 147-162.

28. $\quad P w C$. (2013). Shaping the bank of the future: South African banking survey 2013. Retrieved 11 April 2014 http://www.pwc.co.za/en_ZA/za/assets/pdf/south-african-banking-survey-2013.pdf2014

29. Rice, J. A. (1995). Mathematical statistics and data analysis. Duxbury Press: USA.

30. Rootman, C., Tait, M., \& Sharp, G. (2011). Bank managers' views on relationship marketing. Journal of Contemporary Management, 8(1), 315-336.

31. Rootman, C., Tait, M., \& Bosch, J. (2007). The influence of bank employees on bank customer relationship management. Acta Commercii, 181-192

32. Rose, P. S., \& Hudgins, S. C. (2010). Bank management \& financial services ( $8^{\text {th }}$ ed.). McGraw-Hill: USA.

33. Scholtens, B., \& Van Wensveen, D. (2000). A critique on the theory of financial intermediation. Journal of Banking and Finance, 24(8), 1243-1251.

34. Selden, L., \& MacMillan, I. C. (2006). Manage customer-centric innovation systematically. Harvard Business Review, 84(4), 108-116.

35. Seldon, L. (2007). Customer-centricity: A primer. Journal of Financial Transformation, 21(11), 13-26.

36. Singh, A. M. (2004). Trends in South African Internet banking. Aslib Proceedings: New Information Perspectives, 56(3), 187-196.

37. Singhal, S., \& Vij, M. (2006). Convergence in financial services industry: Trends and issues in regulation and supervision. Journal of Management Research, 6(1), 48-56.

38. Sinkey, J. F. (2002). Commercial bank financial management in the financial-services industry. Pearson Prentice-Hall: USA.

39. Staikouras, S. K. (2006). Business opportunities and market realities in financial conglomerates. The Geneva Papers on Risk and Insurance, 31(1), 124-148.

40. Theron, E., Terblanche, N., \& Boshoff, C. (2008). The antecedents of relationship commitment in the management of relationships in business-to-business (B2B) financial services. Journal of Marketing Management, 24(9-10), 997-1010.

41. Theron, E., \& Terblanche, N. S. (2010). Dimensions of relationship marketing in business-to-business financial services. International Journal of Market Research, 52(3), 383-402. 
42. Yavas, U., Bilgin, Z., \& Shemwell, D. J. (1997). Service quality in the banking sector in an emerging economy: A consumer survey. International Journal of Bank Marketing, 16(6), 217-223.

43. Yavas, U., Benkenstein, M., \& Stuhldreier, U. (2004). Relationships between service quality and behavioural outcomes: A study of private bank customers in Germany. International Journal of Bank Marketing, 22(2), 144-157. 
NOTES 